\title{
Aliskiren suppresses the renin-angiotensin- aldosterone system and reduces blood pressure and albuminuria in elderly chronic kidney disease patients with hypertension
}

\author{
This article was published in the following Dove Press journal: \\ International Journal of Nephrology and Renovascular Disease \\ 20 September 2012 \\ Number of times this article has been viewed
}

\author{
Yoshiyuki Morishita' \\ Toshihiro Yasui ${ }^{2}$ \\ Akihiko Numata' \\ Akira Onishi' \\ Kenichi Ishibashi ${ }^{3}$ \\ Eiji Kusano'
}

'Department of Internal Medicine, Jichi Medical University, Shimotsuke, Japan; ${ }^{2}$ National Health Insurance Yukawa Clinic, Niimi, Japan; ${ }^{3}$ Department of Medical Physiology, Meiji Pharmaceutical University, Tokyo, Japan
Correspondence: Yoshiyuki Morishita Division of Nephrology, Department of Medicine, Jichi Medical University,

33II-I Yakushiji, Shimotsuke,

Tochigi 329-0498, Japan

Tel +8I 285587346

Fax +8I 285444869

Email ymori@jichi.ac.jp
Background: We investigated the effects of aliskiren in terms of its inhibition of the renin-angiotensin-aldosterone system (RAAS) as well as that on blood pressure (BP), and renal and cardiac protection in elderly chronic kidney disease (CKD) patients with hypertension.

Methods: Nineteen elderly CKD patients (nine males, ten females, aged $74.6 \pm 5.8$ years) were assigned to receive $150 \mathrm{mg}$ /day of aliskiren added to existing antihypertensives for 6 months. Changes in plasma renin activity (PRA), angiotensin I (Ang I), angiotensin II (Ang II), aldosterone (Ald), BP, estimated glomerular filtration rate (eGFR), urine albumin/creatinine ratio (UACR), left ventricular ejection fraction (LVEF), interventricular septum thickness (IVST), left ventricular posterior wall thickness (LVPWT), and plasma brain natriuretic peptide (BNP) levels were evaluated.

Results: Aliskiren suppressed the RAAS as follows: PRA $1.3 \pm 1.0$ to $0.3 \pm 0.3 \mathrm{ng} / \mathrm{mL} /$ hour, $P<0.05$; Ang I $59.5 \pm 32.1$ to $26.0 \pm 17.3 \mathrm{pg} / \mathrm{mL}, P<0.05$; Ang II $58.4 \pm 62.1$ to $14.3 \pm 9.0$ $\mathrm{pg} / \mathrm{mL}, P<0.05$; and Ald $86.1 \pm 38.3$ to $80.1 \pm 52.6 \mathrm{pg} / \mathrm{mL}$, not significant (NS). Aliskiren reduced $\mathrm{BP}(153.6 / 77.2 \pm 14.9 / 10.4$ to $130.9 / 72.2 \pm 15.6 / 9.9 \mathrm{mmHg}, P<0.05)$. It also reduced UACR ( $747.1 \pm 1121.4$ to $409.6 \pm 636.8 \mathrm{mg} / \mathrm{g}, P<0.05$ ), whereas it did not change eGFR $\left(52.1 \pm 29.2\right.$ to $\left.51.2 \pm 29.3 \mathrm{~mL} / \mathrm{min} / 1.73 \mathrm{~m}^{2}, \mathrm{NS}\right), \mathrm{LVEF}(66.8 \pm 7.9$ to $66.5 \% \pm 6.8 \%, \mathrm{NS})$, IVST $(10.1 \pm 1.8$ to $9.9 \pm 1.8 \mathrm{~mm}, \mathrm{NS})$, LVPWT $(10.0 \pm 1.6 \mathrm{~mm}$ to $10.0 \pm 1.4 \mathrm{~mm}$, NS), or BNP $(48.2 \pm 46.0$ to $54.9 \pm 41.1 \mathrm{pg} / \mathrm{mL}, \mathrm{NS})$.

Conclusion: Aliskiren was effective for BP control and reduced UACR while maintaining eGFR and heart function in elderly CKD patients with hypertension.

Keywords: aliskiren, renin-angiotensin-aldosterone system, blood pressure, albuminuria, elderly chronic kidney disease

\section{Introduction}

Elderly patients with chronic kidney disease (CKD) have been increasing in association with the increase in the population of elderly people globally. ${ }^{1,2} \mathrm{CKD}$ is a major factor that contributes to the morbidity and mortality of elderly people. ${ }^{3}$ Furthermore, CKD increases the risk of cardiovascular mortality and morbidity. ${ }^{4}$ The renin-angiotensinaldosterone system (RAAS) plays pivotal roles in the pathogenesis of CKD as well as hypertension and cardiovascular disease. ${ }^{5,6}$ Indeed, several studies have reported that the blockade of the RAAS by angiotensin I-converting enzyme inhibitors (ACEIs) and angiotensin-receptor blockers (ARBs) showed beneficial effects on hypertension, CKD, and cardiovascular disease in CKD patients, including the elderly. ${ }^{6-10}$ 
Aliskiren suppresses the RAAS by directly inhibiting plasma renin activity (PRA). ${ }^{11}$ Recently, evidence has accumulated suggesting that aliskiren is effective for blood pressure (BP) control and inhibits the progression of CKD and cardiovascular disease in patients with hypertension and CKD; ${ }^{12-16}$ however, its effects on elderly CKD patients have not been fully elucidated because most clinical trials have excluded the elderly and few studies have targeted elderly CKD patients. In the present study, we assessed the efficacy of aliskiren on BP control, renoprotection, and cardioprotection in elderly CKD patients with hypertension.

\section{Methods}

This study was performed in accordance with the Declaration of Helsinki and was approved by the ethics committee of Jichi Medical University. Written informed consent was obtained from all patients.

\section{Patients}

Between February 2011 and December 2011, 23 elderly patients (over 65 years of age) who had CKD and hypertension were enrolled in this study. CKD was defined as the estimated glomerular filtration rate (eGFR) being $>15$ and $\leq 60 \mathrm{~mL} / \mathrm{minute} / 1.73 \mathrm{~m}^{2}$ and/or the urine albumin/ creatinine ratio (UACR) being $>30 \mathrm{mg} / \mathrm{g}$. Hypertension was defined by clinical systolic BP (SBP) $\geq 140 \mathrm{mmHg}$ and diastolic $\mathrm{BP}(\mathrm{DBP}) \geq 90 \mathrm{mmHg}$. Exclusion criteria were as follows: type I diabetes mellitus or type II diabetes mellitus with poor glucose control (glycosylated hemoglobin $\left[\mathrm{HbA}_{1 \mathrm{c}}\right]>9 \%$ at the start of the observation period), hyperpotassemia $(>5.5 \mathrm{mEq} / \mathrm{mL})$, history of stroke, coronary heart disease, severe arrhythmia, or any medical or surgical condition that may have affected the pharmacokinetics of the study drug. The patients who had decreased eGFR ( $<60 \mathrm{~mL} /$ minute $\left./ 1.73 \mathrm{~m}^{2}\right)$ with diabetic mellitus and who had been receiving ACEIs or ARBs were suspended in this study in accordance with the results of the ALTITUDE study, which showed that adverse effects such as stroke, renal impairment, hyperkalemia, and hypotension were observed in patients who received aliskiren added to ACEIs or ARBs among highrisk patients with diabetes and renal impairment than in patients who received a placebo.

\section{Study protocol}

This was a 28-week, multicenter study consisting of a 4-week observation period to fix any drugs, including existing antihypertensives, and a 24-week treatment period with aliskiren.
After the 4-week observation period, all eligible patients entered the 24-week treatment period, during which they received aliskiren at $150 \mathrm{mg}$ orally in the morning once daily. BP was measured at a clinic when they consulted primary care physicians. The reported BP was the average of three measurements. eGFR, plasma potassium, plasma BNP, plasma PRA, plasma angiotensin I (Ang I), plasma angiotensin II (Ang II), and plasma aldosterone (Ald) levels were measured at baseline and week 24 in the treatment period. UACR was measured at baseline and at week 12 and week 24 in the treatment period. Left ventricular ejection fraction (LVEF), interventricular septum thickness (IVST), and left ventricular posterior wall thickness (LVPWT) were measured by echocardiogram at baseline and week 24 in the treatment period. Standard laboratory tests were performed in the observation period and at baseline, and weeks 12 and 24 in the treatment period.

\section{Laboratory methods}

eGFR was calculated using a modified version of the Modification of Diet in Renal Disease formula of the Japanese Society of Nephrology, as follows: eGFR $\left(\mathrm{mL} /\right.$ minute $\left./ 1.73 \mathrm{~m}^{2}\right)=194 \times$ age $^{-0.287} \times$ serum creatinine $^{-1.094}$ (multiplied by 0.739 for females). ${ }^{17}$ Microalbuminuria was defined as UACR of $>30 \mathrm{mg} / \mathrm{g}$ and $<300 \mathrm{mg} / \mathrm{g}$. Macroalbuminuria was defined as UACR $>300 \mathrm{mg} / \mathrm{g}$.

Plasma BNP, PRA and Ald levels were determined by radioimmunoassay. Plasma Ang I and Ang II levels were measured by double-antibody radioimmunoassay; the details of these methods have been described elsewhere. ${ }^{18,19}$ PRA, Ang I, Ang II and other blood-chemistry parameters were determined by a clinical chemistry laboratory (SRL, Tokyo, Japan).

\section{Statistical analysis}

All data are expressed as the mean \pm standard deviation (SD). Mann-Whitney test or repeated-measures analysis of variance was used to compare continuous data. Differences with a $P$-value $<0.05$ were considered significant.

\section{Results}

Twenty-three patients entered the treatment period after the 1-month observation period (Figure 1). Nineteen patients completed the study. One discontinued the study owing to the development of a hemodynamically unstable condition associated with severe viral infection with herpes zoster. One discontinued the study owing to dizziness. The dizziness was resolved after aliskiren withdrawal. One discontinued the 


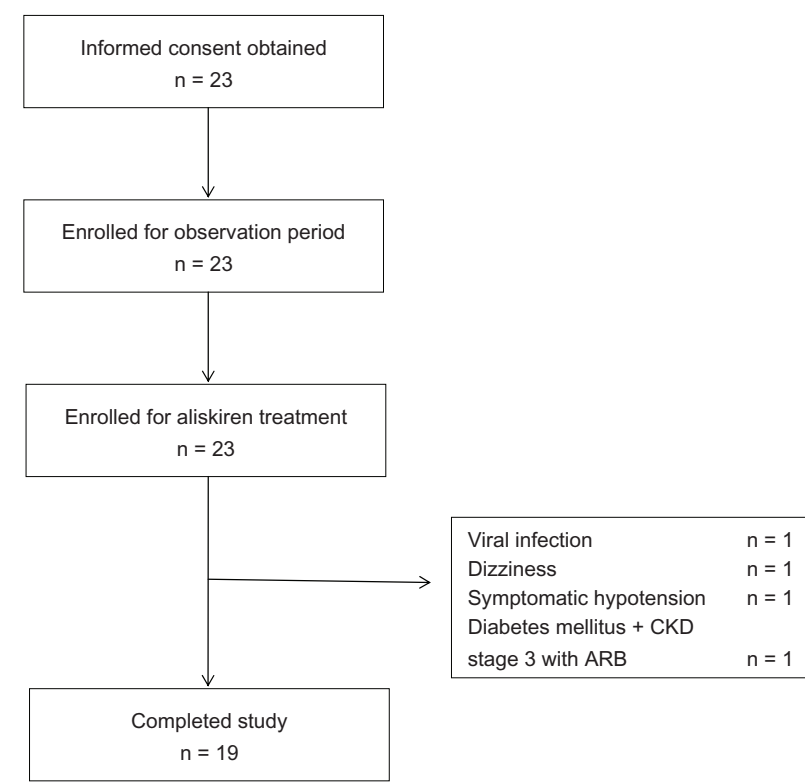

Figure I Patient flow chart.

Abbreviations: CKD, chronic kidney disease; ARB, angiotensin-receptor blockers.

study owing to symptomatic hypotension. The symptomatic hypotension recovered to the basal level after aliskiren withdrawal. One discontinued the study and suspended aliskiren treatment; he was excluded from this study because he had decreased eGFR $\left(<60 \mathrm{~mL} /\right.$ minute $\left./ 1.73 \mathrm{~m}^{2}\right)$ and diabetes mellitus with treatment of an ARB, in accordance with the results of the ALTITUDE study. However, he did not have any side effects upon the addition of aliskiren. Increased serum potassium was not observed in any patients. Table 1 shows the characteristics of the study patients. The study patients were nine males and ten females, and their average age was $74.6 \pm 5.8$ years (range 65.0-84.7 years). Their average eGFR was $52.1 \pm 29.2 \mathrm{~mL} / \mathrm{minute} / 1.73 \mathrm{~m}^{2}$ and average UACR was $747.1 \pm 1121.4 \mathrm{mg} / \mathrm{g}$. Nine patients had microalbuminuria (UACR: $111.3 \pm 79.8 \mathrm{mg} / \mathrm{g}$ ) and seven patients had macroalbuminuria (UACR: $1877.9 \pm 1182.6 \mathrm{mg} / \mathrm{g}$ ). All patients had been taking antihypertensive drugs before the treatment period, including calcium antagonists (18 patients), AECIs (two patients), ARBs (16 patients), $\beta$-blockers (one patient), $\alpha$-blockers (seven patients), $\alpha \beta$-blockers (two patients), and diuretics (four patients). Details of antihypertensive drugs in each patient are shown in Table 2. None of the patients had their BP well controlled, despite the use of antihypertensives prior to aliskiren treatment.

\section{Blockade of RAAS by aliskiren}

The blockade effect of RAAS by aliskiren in the patients is shown in Figure 2. PRA decreased from $1.3 \pm 1.0 \mathrm{ng} / \mathrm{mL} /$ hour at baseline to $0.3 \pm 0.3 \mathrm{ng} / \mathrm{mL} /$ hour at week $24(P<0.05)$.
Table I Patient baseline characteristics $(n=19)$

\begin{tabular}{|c|c|}
\hline Parameter & Statistics \\
\hline \multirow[t]{2}{*}{ Age (years) } & $74.6 \pm 5.8$ \\
\hline & $(65.0-84.7)$ \\
\hline \multicolumn{2}{|l|}{ Sex } \\
\hline Male & 9 \\
\hline Female & 10 \\
\hline BMI $\left(\mathrm{kg} / \mathrm{m}^{2}\right)$ & $25.4 \pm 6.0$ \\
\hline \multicolumn{2}{|l|}{ CKD } \\
\hline Stage I & I \\
\hline Stage 2 & 9 \\
\hline Stage 3 & 3 \\
\hline Stage 4 & 3 \\
\hline Stage 5 & 3 \\
\hline $\mathrm{SBP}(\mathrm{mmHg})$ & $153.6 \pm 14.9$ \\
\hline $\mathrm{DBP}(\mathrm{mmHg})$ & $77.2 \pm 10.4$ \\
\hline HR (beats/minute) & $63.3 \pm 10.6$ \\
\hline Creatinine (mg/dL) & $1.4 \pm 1.0$ \\
\hline eGFR (mL/minute/l.73 $\left.\mathrm{m}^{2}\right)$ & $52.1 \pm 29.2$ \\
\hline UACR (mg/g) & $747.1 \pm \mid 121.4$ \\
\hline PRA (ng/mL/hour) & $1.3 \pm 1.0$ \\
\hline Ang I (pg/mL) & $59.5 \pm 32.1$ \\
\hline Ang 2 (pg/mL) & $58.4 \pm 62.1$ \\
\hline Ald $(\mathrm{pg} / \mathrm{mL})$ & $86.1 \pm 38.3$ \\
\hline $\mathrm{BNP}(\mathrm{pg} / \mathrm{mL})$ & $48.2 \pm 46.0$ \\
\hline LVEF (\%) & $66.8 \pm 7.9$ \\
\hline IVST (mm) & $10.1 \pm 1.8$ \\
\hline LVPWT (mm) & $10.0 \pm 1.6$ \\
\hline
\end{tabular}

Abbreviations: BMI, body mass index; CKD, chronic kidney disease; SBP, systolic blood pressure; DBP, diastolic blood pressure; HR, heart rate; eGFR, estimated glomerular filtration rate; UACR, urinary albumin/creatinine ratio; PRA, plasma renin activity; Ang I, angiotensin I; Ang 2, angiotensin II; Ald, aldosterone; BNP, brain natriuretic peptide; LVEF, left ventricular ejection fraction; IVST, interventricular septum thickness; LVPWT, left ventricular posterior wall thickness.

Ang I decreased from $59.5 \pm 32.1 \mathrm{pg} / \mathrm{mL}$ at baseline to $26.0 \pm 17.3 \mathrm{pg} / \mathrm{mL}$ at week $24(P<0.05)$. Ang II decreased from $58.4 \pm 62.1 \mathrm{pg} / \mathrm{mL}$ at baseline to $14.3 \pm 9.0 \mathrm{pg} / \mathrm{mL}$ at week $24(P<0.05)$. Aldosterone (Ald) decreased from $86.1 \pm 38.3 \mathrm{pg} / \mathrm{mL}$ at baseline to $80.1 \pm 52.6 \mathrm{pg} / \mathrm{mL}$ at week 24 (not significant).

\section{Effect of aliskiren on BP}

$\mathrm{SBP}( \pm \mathrm{SD})$ decreased from $153.6 \pm 14.9 \mathrm{mmHg}$ at baseline to $130.9 \pm 15.6 \mathrm{mmHg}$ at week $24(P<0.05)$ (Figure 3$)$. DBP $( \pm \mathrm{SD})$ also decreased from $77.2 \pm 10.4 \mathrm{mmHg}$ at baseline to $72.2 \pm 9.9 \mathrm{mmHg}$ at week $24(P<0.05)$ (Figure 3$)$.

\section{Effect of aliskiren on UACR and eGFR}

UACR (all patients: $\mathrm{n}=19$ ) decreased from $747.1 \pm 1121.4 \mathrm{mg} / \mathrm{g}$ at baseline to $480.5 \pm 791.2 \mathrm{mg} / \mathrm{g}$ at week $12(P<0.05)$, followed by a further decrease to $409.6 \pm 636.8 \mathrm{mg} / \mathrm{g}$ at week $24(P<0.05)$ (Figure $4 \mathrm{~A})$. In the subanalysis of the microalbuminuria and macroalbuminuria groups, 
Table 2 Patient clinical characteristics before aliskiren treatment

\begin{tabular}{|c|c|c|c|c|c|c|c|}
\hline No & CKD stage & $\begin{array}{l}\text { eGFR } \\
\left(\mathrm{mL} / \text { minute/ } / .73 \mathrm{~m}^{2}\right)\end{array}$ & Sex & $\begin{array}{l}\text { Age } \\
\text { (years) }\end{array}$ & $\begin{array}{l}\text { Antihypertensives } \\
\text { (day) }\end{array}$ & $\begin{array}{l}\text { SBP } \\
(\mathrm{mmHg})\end{array}$ & $\begin{array}{l}\text { DBP } \\
(\mathrm{mmHg})\end{array}$ \\
\hline 1 & I & 105.6 & Male & 71.6 & $\begin{array}{l}\text { Amlodipine } 5 \mathrm{mg} \\
\text { Telmisartan } 40 \mathrm{mg}\end{array}$ & 203 & 83 \\
\hline 2 & 2 & 89.6 & Female & 72.8 & $\begin{array}{l}\text { Olmesartan } 20 \mathrm{mg} \\
\text { Amlodipine } 5 \mathrm{mg}\end{array}$ & 157 & 61 \\
\hline 3 & 2 & 82.8 & Male & 68.3 & $\begin{array}{l}\text { Olmesartan } 40 \mathrm{mg} \\
\text { Azelnidipine } 16 \mathrm{mg} \\
\text { Doxazosin } 2 \mathrm{mg}\end{array}$ & 162 & 84 \\
\hline 4 & 2 & 78.0 & Male & 84.4 & $\begin{array}{l}\text { Olmesartan } 20 \mathrm{mg} \\
\text { Torasemide } 4 \mathrm{mg} \\
\text { Azelnidipine } 16 \mathrm{mg}\end{array}$ & 160 & 78 \\
\hline 5 & 2 & 74.0 & Female & 75.7 & $\begin{array}{l}\text { Azelnidipine } 16 \mathrm{mg} \\
\text { Valsartan } 80 \mathrm{mg} \\
\text { Trichlormethiazide I mg }\end{array}$ & 140 & 80 \\
\hline 6 & 2 & 71.3 & Female & 75.3 & $\begin{array}{l}\text { Olmesartan } 20 \mathrm{mg} \\
\text { Azelnidipine } 16 \mathrm{mg}\end{array}$ & 150 & 70 \\
\hline 7 & 2 & 70.3 & Female & 84.9 & $\begin{array}{l}\text { Olmesartan } 20 \mathrm{mg} \\
\text { Ateolol } 50 \mathrm{mg} \\
\text { Azelnidipine } 16 \mathrm{mg}\end{array}$ & 151 & 60 \\
\hline 8 & 2 & 64.8 & Female & 73.3 & $\begin{array}{l}\text { Azelnidipine } 16 \mathrm{mg} \\
\text { Olmesartan } 20 \mathrm{mg} \\
\text { Doxazosin } 2 \mathrm{mg} \\
\text { Furosemide } 20 \mathrm{mg}\end{array}$ & 154 & 71 \\
\hline 9 & 2 & 60.9 & Female & 73.5 & $\begin{array}{l}\text { Amlodipine } 5 \mathrm{mg} \\
\text { Doxazosin } 2 \mathrm{mg}\end{array}$ & $14 \mid$ & 73 \\
\hline 10 & 2 & 60.8 & Male & 84.7 & $\begin{array}{l}\text { Olmesartan } 20 \mathrm{mg} \\
\text { Amlodipine } 5 \mathrm{mg} \\
\text { Carvedilol } 5 \mathrm{mg}\end{array}$ & 159 & 76 \\
\hline II & 3 & 54.4 & Male & 72.0 & $\begin{array}{l}\text { Amlodipine } 5 \mathrm{mg} \\
\text { Temocapril } 4 \mathrm{mg} \\
\text { Doxazosin } 2 \mathrm{mg}\end{array}$ & 155 & 99 \\
\hline 12 & 3 & 42.7 & Female & 64.9 & $\begin{array}{l}\text { Telmisartan } 40 \mathrm{mg} \\
\text { Amlodipine } 5 \mathrm{mg}\end{array}$ & 140 & 76 \\
\hline 13 & 3 & 32.8 & Female & 76.2 & $\begin{array}{l}\text { Candesartan } 4 \mathrm{mg} \\
\text { Benidipine } 4 \mathrm{mg}\end{array}$ & 143 & 68 \\
\hline 14 & 4 & 24.1 & Male & 73.5 & $\begin{array}{l}\text { Amlodipine } 10 \mathrm{mg} \\
\text { Candesartan } 8 \mathrm{mg}\end{array}$ & 156 & 94 \\
\hline 15 & 4 & 19.8 & Female & 76 & $\begin{array}{l}\text { Azelnidipine } 8 \mathrm{mg} \\
\text { Azelnidipine } 16 \mathrm{mg}\end{array}$ & 140 & 70 \\
\hline 16 & 4 & 18.6 & Male & 65.9 & $\begin{array}{l}\text { Nifedipine } 40 \mathrm{mg} \\
\text { Olmesartan } 20 \mathrm{mg} \\
\text { Doxazosin } 8 \mathrm{mg} \\
\text { Temocapril } 4 \mathrm{mg} \\
\text { Carvedilol } 5 \mathrm{mg} \\
\text { Furosemide } 60 \mathrm{mg}\end{array}$ & $|4|$ & 86 \\
\hline 17 & 5 & 14.5 & Female & 73 & $\begin{array}{l}\text { Amlodipine } 5 \mathrm{mg} \\
\text { Candesartan } 8 \mathrm{mg}\end{array}$ & 148 & 70 \\
\hline 18 & 5 & 12.3 & Male & 81.1 & $\begin{array}{l}\text { Cilndipine } 20 \mathrm{mg} \\
\text { Doxazosin } 2 \mathrm{mg} \\
\text { Telmisartan } 10 \mathrm{mg}\end{array}$ & 147 & 78 \\
\hline 19 & 5 & 12.0 & Male & 70.4 & $\begin{array}{l}\text { Amlodipine } 5 \mathrm{mg} \\
\text { Olmesartan } 20 \mathrm{mg}\end{array}$ & $17 \mid$ & 90 \\
\hline
\end{tabular}

Abbreviations: CKD, chronic kidney disease; eGFR, estimated glomerular filtration rate; SBP, systolic blood pressure; DBP, diastolic blood pressure.

microalbuminuria $(\mathrm{n}=9)$ decreased from $111.3 \pm 79.8 \mathrm{mg} / \mathrm{g}$ to $65.6 \pm 79.5 \mathrm{mg} / \mathrm{g}$ at week $12(P<0.05)$, followed by a further decrease to $53.2 \pm 52.3 \mathrm{mg} / \mathrm{g}$ at week $24(P<0.05)$, and macroalbuminuria $(\mathrm{n}=7)$ also decreased from $1878.0 \pm 1182.6 \mathrm{mg} / \mathrm{g}$ to $1214.1 \pm 935.3$ (not significant), followed by a further decrease to $1039.7 \pm 692.0$ at week $24(P<0.05)$ (Figure 4A). The eGFR did not significantly change during the treatment period $\left(52.1 \pm 29.2 \mathrm{~mL} /\right.$ minute $/ 1.73 \mathrm{~m}^{2}$ at baseline vs $51.2 \pm 29.3 \mathrm{~mL} /$ minute $/ 1.73 \mathrm{~m}^{2}$ at week 24 ) (Figure 4B). 
PRA

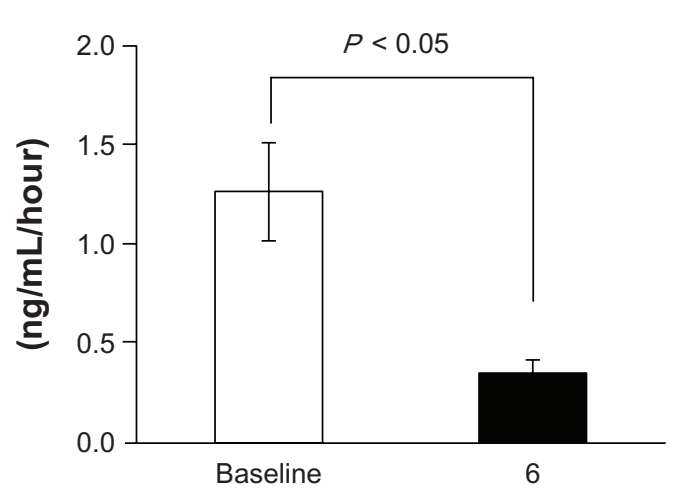

Months

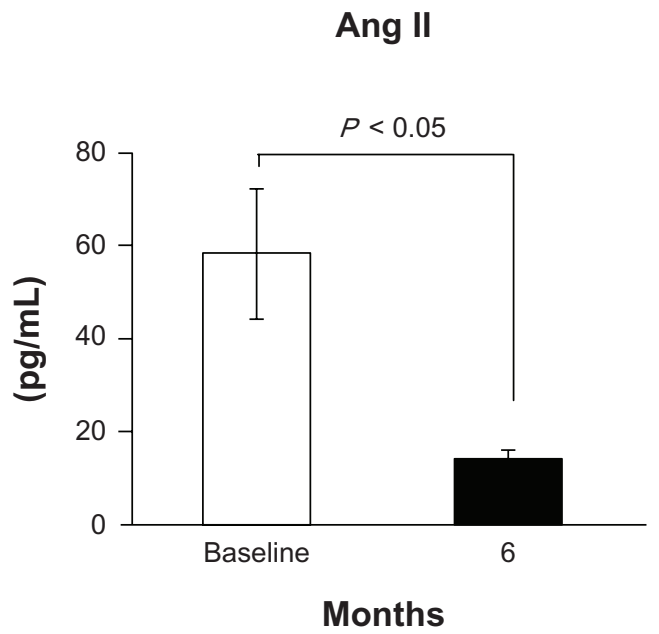

Ang I

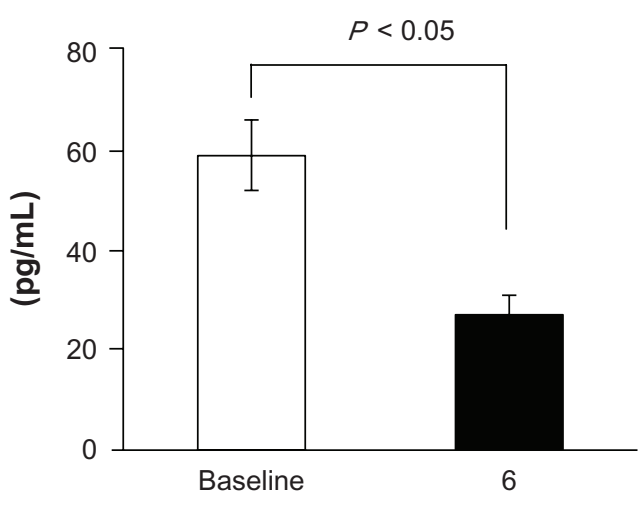

Months

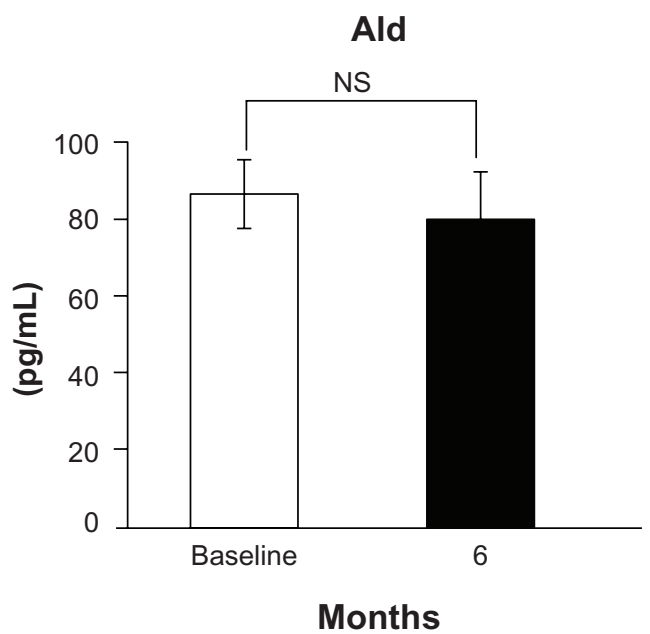

Figure 2 Changes in plasma renin activity (PRA), angiotensin I (Ang I), angiotensin II (Ang II) and aldosterone (Ald) upon aliskiren treatment. Abbreviation: NS, not significant.

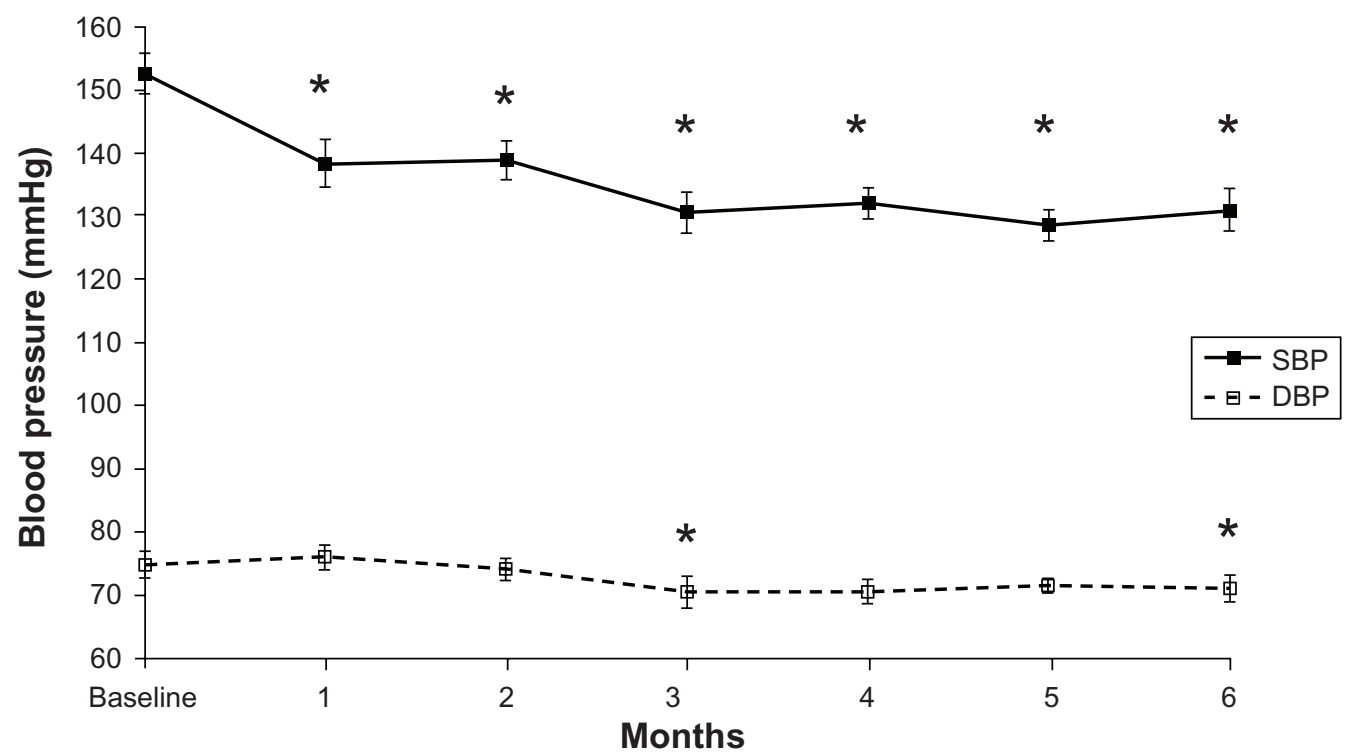

Figure 3 Changes in systolic blood pressure (SBP) and diastolic blood pressure (DBP) from baseline to week 24. Note: $* P<0.05$ compared with the value at baseline. 
A

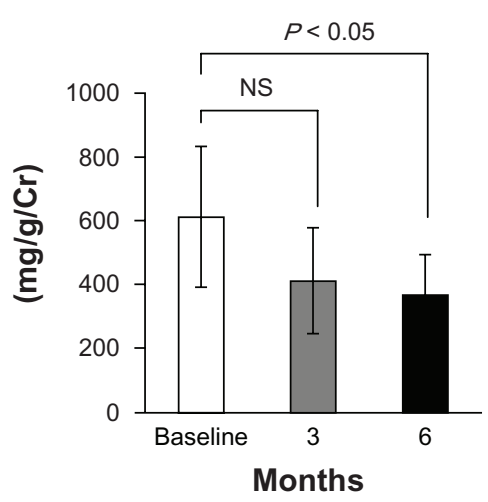

UACR (microalbuminuria)

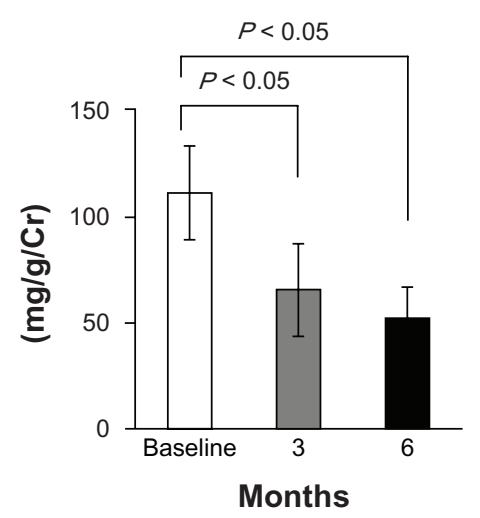

B

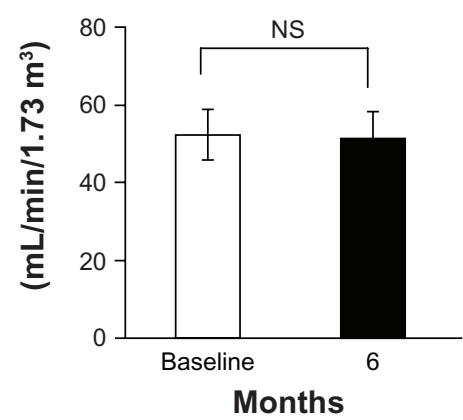

UACR (macroalbuminuria)

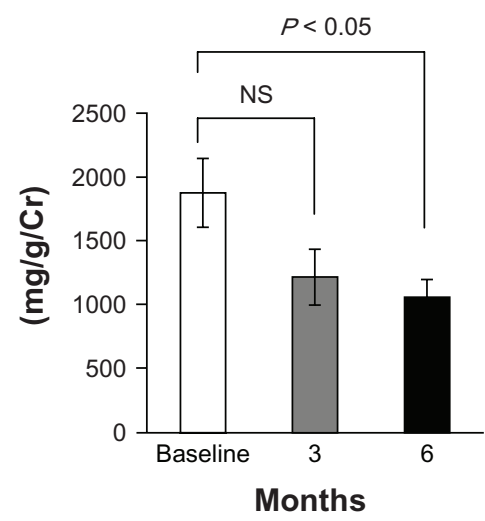

Figure 4 Changes in urine albumin/creatinine ratio $(\mathrm{UACR})$ (all patients: $n=19)$, UACR with microalbuminuria $(n=7)$, and $U A C R$ with macroalbuminuria $(n=9)(A)$, and estimated glomerular filtration ratio (eGFR) (B) upon aliskiren treatment.

Abbreviation: NS, not significant.

\section{Effect of aliskiren on heart function and plasma BNP level}

LVEF did not change during the treatment period $(66.8 \% \pm 7.9 \%$ at baseline vs $66.5 \% \pm 6.8 \%$ at week 24 ) (Figure $5 \mathrm{~A}$ ). IVST and LVPWT did not change in the treatment period (IVST, $10.1 \pm 1.8 \mathrm{~mm}$ at baseline vs $9.9 \pm 1.8 \mathrm{~mm}$ at week 248 ; LVPWT, $10.0 \pm 1.6 \mathrm{~mm}$ at baseline vs $10.0 \pm 1.4 \mathrm{~mm}$ at week 24) either. Also, plasma BNP level did not change during the treatment period $(48.2 \pm 46.0 \mathrm{pg} / \mathrm{mL}$ at baseline vs $54.9 \pm 41.1 \mathrm{pg} / \mathrm{mL}$ at week 24) (Figure 5B).

\section{Discussion}

The results of this study show that aliskiren suppressed RAAS and significantly decreased BP and UACR, whereas it did not change eGFR, LVEF, IVST, LVPWT, and BNP levels in elderly CKD patients with hypertension. Among RAAS components, PRA, Ang I, and Ang II were significantly decreased by aliskiren in elderly CKD patients in this study; however, aldosterone was not decreased. These results may suggest the possibility that aliskiren cannot overcome aldosterone breakthrough in the same way as ACEIs and ARBs in elderly CKD patients can.

Hypertension has a high impact on the decline of renal function and the development of cardiovascular disease in elderly patients. ${ }^{20-22}$ The subanalysis of Systolic Hypertension in the Elderly Program showed that SBP is a strong, independent predictor of a decline in renal function among elderly patients. ${ }^{21}$ Okada et al also reported that SBP is a significant predictor of decline in renal function and the development of end-stage renal failure in elderly CKD patients. ${ }^{22}$ The Hypertension in the Very Elderly Trial reported that cardiovascular events were significantly less common in the decreased BP group (143.5/77.9 $\mathrm{mmHg})$ with antihypertensives than in the placebo group $(158.5 / 84.0 \mathrm{mmHg})$ among elderly patients. ${ }^{20}$ In this study, the enrolled patients' BP was not controlled well, despite antihypertensives prior to aliskiren treatment. The dose of each antihypertensive may not have been enough to control their BP.

In addition, CKD itself is a major risk factor for cardiovascular disease. Several studies have reported that CKD 
A

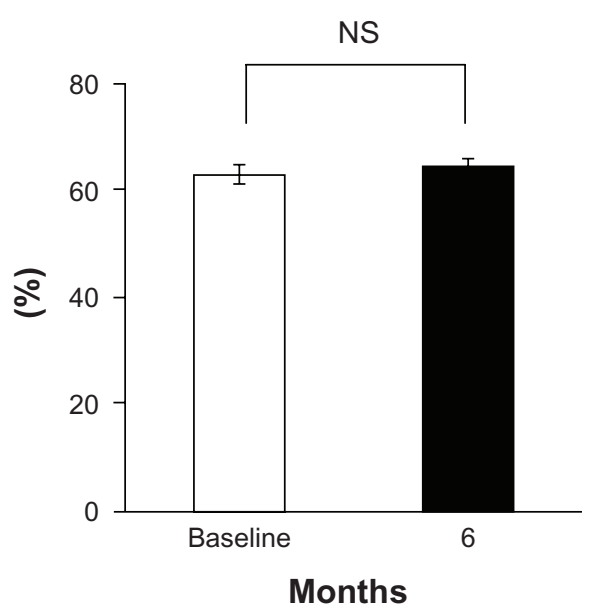

B

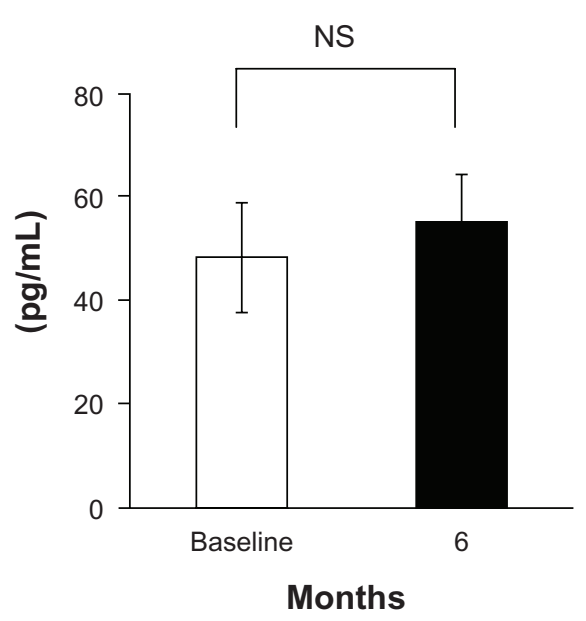

Figure 5 Changes in left ventricular ejection fraction (LVEF) (A) and plasma brain natriuretic peptide (BNP) level (B) upon aliskiren treatment. Abbreviation: NS, not significant.

increases the risk of cardiovascular disease in elderly hypertensive patients. ${ }^{4,23}$ Although the stage of CKD is defined by GFR, albuminuria is also an independent risk factor for the development of end-stage renal disease and cardiovascular disease in CKD patients. ${ }^{24-26}$ The risk of renal events was increased substantially more by microalbuminuria, even in the same GFR patients. ${ }^{24}$ The risk of cardiovascular disease was also increased by microalbuminuria, and it was further increased with decreased GFR in CKD patients. ${ }^{26}$ Macroalbuminuria is also a risk factor for accelerated decline of renal function. ${ }^{25}$ These lines of evidence suggested that decreased BP and albuminuria could inhibit the progress of CKD and the development of cardiovascular disease in elderly CKD patients. In the present study, aliskiren decreased BP, microalbuminuria, and macroalbuminuria, while it did not change eGFR, LVEF, VST, LVPWT, or plasma BNP levels in elderly CKD patients. These results suggest that aliskiren has beneficial effects on BP control and renoprotection, which may lead to inhibition of the development of cardiovascular disease in elderly CKD patients. The effects of aliskiren for albuminuria, eGFR, LVEF, VST, LVPWT, and plasma BNP did not change between early stage CKD (stages 1 and 2) and advanced-stage CKD (stages 3-5) (data not shown). It should be noted that renal replacement therapies, while paying attention to the risk of a decrease of residual renal function, could be alternative therapies to manage hypertension in the stage $5 \mathrm{CKD}$ patients in this study.

The albuminuria decreased in accordance with BP reduction in this study. These results suggested aliskiren may decrease albuminuria, mainly by a BP-lowering effect in the elderly CKD patients in this study. Although not statistically significant, plasma BNP levels tended to increase from baseline to week 24. Since BNP reduction has consistently been associated with an improved outcome in heart failure, ${ }^{27,28}$ aliskiren may not have beneficial effects for heart function in elderly CKD patients with hypertension. Further large-scale and long-term studies will need to investigate the effects and mechanism of renoprotection and cardioprotection of aliskiren in elderly CKD patients.

Several clinical studies have demonstrated that aliskiren is effective for hypertension by monotherapy and combination therapy with other antihypertensives such as ACEIs, ARBs, and calcium antagonists in elderly hypertensive patients; ${ }^{16,29}$ however, recently the ALTITUDE study investigating the effects of aliskiren added to ACEIs or ARBs in patients at high risk for cardiovascular disease and with diabetes and renal impairment was suspended because more adverse effects such as stroke, renal impairment, hyperkalemia, and hypotension were observed in patients who received aliskiren than in patients who received a placebo. In accordance with the results of that study, one patient who had decreased eGFR $\left(<60 \mathrm{~mL} /\right.$ minute $\left./ 1.73 \mathrm{~m}^{2}\right)$ with diabetes mellitus treated with an ARB were suspended in this study at a time when he did not have any adverse events upon the addition of aliskiren. Although many patients in the present study who received aliskiren had been taking ACEIs (2/23 patients) or ARBs (16/23 patients), no patients developed any serious adverse events. The patients in the present study maintained their cardiac function and had no complication of diabetes mellitus. These conditions of the patients may have affected the fact 
that serious side effects of aliskiren with ARBs or ACEIs were not observed in elderly CKD patients in the present study. The further studies investigating the effects and safety of aliskiren, including its combination with ACEIs and ARBs, will be required in elderly $\mathrm{CKD}$ patients.

There are several limitations in this study. First, it was a single-arm trial without a control group. Second, the number of patients was small and treatment period was short. Therefore, the results may not reflect outcomes shown in previous large-scale trials such as the ALTITUDE study. Further large-scale, double-blind, long-term clinical trials will need to investigate the effects of aliskiren in elderly CKD patients.

In conclusion, aliskiren reduced BP and UACR while maintaining eGFR, LVEF, and plasma BNP levels in elderly CKD patients with hypertension, which may inhibit the development of cardiovascular disease.

\section{Disclosure}

The authors report no conflicts of interest in this work.

\section{References}

1. Imai E, Horio M, Iseki $\mathrm{K}$, et al. Prevalence of chronic kidney disease (CKD) in the Japanese general population predicted by the MDRD equation modified by a Japanese coefficient. Clin Exp Nephrol. 2007;11(2): 156-163.

2. Coresh J, Selvin E, Stevens LA, et al. Prevalence of chronic kidney disease in the United States. JAMA. 2007;298(17):2038-2047.

3. Coresh J, Astor BC, Greene T, Eknoyan G, Levey AS. Prevalence of chronic kidney disease and decreased kidney function in the adult US population: third National Health and Nutrition Examination Survey. Am J Kidney Dis. 2003;41(1):1-12.

4. Ritz E. Minor renal dysfunction: an emerging independent cardiovascular risk factor. Heart. 2003;89(9):963-964.

5. Ferrario CM, Strawn WB. Role of the renin-angiotensin-aldosterone system and proinflammatory mediators in cardiovascular disease. $\mathrm{Am} \mathrm{J}$ Cardiol. 2006;98(1):121-128.

6. Ruster C, Wolf G. Renin-angiotensin-aldosterone system and progression of renal disease. J Am Soc Nephrol. 2006;17(11):2985-2991.

7. Ruggenenti P, Perna A, Remuzzi G. ACE inhibitors to prevent end-stage renal disease: when to start and why possibly never to stop: a post hoc analysis of the REIN trial results. Ramipril Efficacy in Nephropathy. J Am Soc Nephrol. 2001;12(12):2832-2837.

8. Lewis EJ, Hunsicker LG, Clarke WR, et al. Renoprotective effect of the angiotensin-receptor antagonist irbesartan in patients with nephropathy due to type 2 diabetes. $N$ Engl J Med. 2001;345(12):851-860.

9. Berl T, Hunsicker LG, Lewis JB, et al. Cardiovascular outcomes in the Irbesartan Diabetic Nephropathy Trial of patients with type 2 diabetes and overt nephropathy. Ann Intern Med. 2003;138(7):542-549.

10. Brenner BM, Cooper ME, de Zeeuw D, et al. Effects of losartan on renal and cardiovascular outcomes in patients with type 2 diabetes and nephropathy. N Engl J Med. 2001;345(12):861-869.

11. Nussberger J, Wuerzner G, Jensen C, Brunner HR. Angiotensin II suppression in humans by the orally active renin inhibitor Aliskiren (SPP100): comparison with enalapril. Hypertension. 2002;39(1): E1-E8.
12. Ito S, Nakura N, Le Breton S, Keefe D. Efficacy and safety of aliskiren in Japanese hypertensive patients with renal dysfunction. Hypertens Res. 2010;33(1):62-66.

13. Persson F, Rossing P, Schjoedt KJ, et al. Time course of the antiproteinuric and antihypertensive effects of direct renin inhibition in type 2 diabetes. Kidney Int. 2008;73(12):1419-1425.

14. Morishita Y, Hanawa S, Chinda J, Iimura O, Tsunematsu S, Kusano E. Effects of aliskiren on blood pressure and the predictive biomarkers for cardiovascular disease in hemodialysis-dependent chronic kidney disease patients with hypertension. Hypertens Res. 2011;34(3):308-313.

15. Parving HH, Persson F, Lewis JB, Lewis EJ, Hollenberg NK. Aliskiren combined with losartan in type 2 diabetes and nephropathy. $N$ Engl J Med. 2008;358(23):2433-2446.

16. McMurray JJ, Pitt B, Latini R, et al. Effects of the oral direct renin inhibitor aliskiren in patients with symptomatic heart failure. Circ Heart Fail. 2008;1(1):17-24.

17. Matsuo S, Imai E, Horio M, et al. Revised equations for estimated GFR from serum creatinine in Japan. Am J Kidney Dis. 2009;53(6): 982-992.

18. Rodbard D. Statistical quality control and routine data processing for radioimmunoassays and immunoradiometric assays. Clin Chem. 1974;20(10):1255-1270.

19. Emanuel RL, Cain JP, Williams GH. Double antibody radioimmunoassay of renin activity and angiotensin II in human peripheral plasma. J Lab Clin Med. 1973;81(4):632-640.

20. Beckett NS, Peters R, Fletcher AE, et al. Treatment of hypertension in patients 80 years of age or older. $N$ Engl J Med. 2008;358(18): 1887-1898.

21. Young JH, Klag MJ, Muntner P, Whyte JL, Pahor M, Coresh J. Blood pressure and decline in kidney function: findings from the Systolic Hypertension in the Elderly Program (SHEP). J Am Soc Nephrol. 2002;13(11):2776-2782.

22. Okada T, Nakao T, Matsumoto H, et al. Prognostic significance of home blood pressure control on renal and cardiovascular outcomes in elderly patients with chronic kidney disease. Hypertens Res. 2009;32(12):1123-1129.

23. Henry RM, Kostense PJ, Bos G, et al. Mild renal insufficiency is associated with increased cardiovascular mortality: the Hoorn Study. Kidney Int. 2002;62(4):1402-1407.

24. Ishani A, Grandits GA, Grimm RH, et al. Association of single measurements of dipstick proteinuria, estimated glomerular filtration rate, and hematocrit with 25-year incidence of end-stage renal disease in the multiple risk factor intervention trial. $\mathrm{J} \mathrm{Am} \mathrm{Soc} \mathrm{Nephrol.}$ 2006;17(5):1444-1452.

25. Halbesma N, Kuiken DS, Brantsma AH, et al. Macroalbuminuria is a better risk marker than low estimated GFR to identify individuals at risk for accelerated GFR loss in population screening. J Am Soc Nephrol. 2006;17(9):2582-2590.

26. Tonelli M, Jose P, Curhan G, Sacks F, Braunwald E, Pfeffer M. Proteinuria, impaired kidney function, and adverse outcomes in people with coronary disease: analysis of a previously conducted randomised trial. BMJ. 2006;332(7555):1426.

27. Latini R, Masson S, Anand I, et al. The comparative prognostic value of plasma neurohormones at baseline in patients with heart failure enrolled in Val-HeFT. Eur Heart J. 2004;25(4):292-299.

28. Jourdain P, Jondeau G, Funck F, et al. Plasma brain natriuretic peptideguided therapy to improve outcome in heart failure: the STARS-BNP Multicenter Study. J Am Coll Cardiol. 2007;49(16):1733-1739.

29. Schmieder RE, Philipp T, Guerediaga J, et al. Long-term antihypertensive efficacy and safety of the oral direct renin inhibitor aliskiren: a 12-month randomized, double-blind comparator trial with hydrochlorothiazide. Circulation. 2009;119(3):417-425. 
International Journal of Nephrology and Renovascular Disease

Dovepress

\section{Publish your work in this journal}

The International Journal of Nephrology and Renovascular Disease is an international, peer-reviewed open-access journal focusing on the pathophysiology of the kidney and vascular supply. Epidemiology, screening, diagnosis, and treatment interventions are covered as well as basic science, biochemical and immunological studies. The journal welcomes

original research, clinical studies, reviews \& evaluations, expert opinion and commentary, case reports and extended reports. The manuscript management system is completely online and includes a very quick and fair peerreview system, which is all easy to use. Visit http://www.dovepress.com/ testimonials.php to read real quotes from published authors.

Submit your manuscript here: http://www.dovepress.com/international-journal-of-nephrology-and-renovascular-disease-journal 